\title{
The Influence of Training, Placement and Motivation on the Performance of Employees of Balai Besar Bahan dan Barang Teknik (B4T) Bandung
}

\author{
Ekko Harjanto $^{1}$, Aida Vitayala Hubeis ${ }^{2}$, M. Joko Affandi ${ }^{3}$ \\ ${ }^{1}$ Postgraduated Program of Management and Business, Bogor Agricultural University, Jl. Raya Pajajaran, Bogor - Indonesia 16151 \\ ${ }^{2}$ Faculty of Human Ecology, Bogor Agricultural University, Jl. Lingkar Kampus, Kampus IPB Dramaga Bogor, 16680 - Indonesia \\ ${ }^{3}$ Faculty of Human Ecology, Bogor Agricultural University, Jl. Lingkar Kampus, Kampus IPB Dramaga Bogor, 16680 - Indonesia
}

\begin{abstract}
The growth of institutions engaged in technical services business is a challenge in improving service quality and industrial competitiveness for B4T. Conducive business climate supports the growth of B4T customers. This research is descriptive research by using census which aims to obtain description of a condition or condition about the effect of training, placement and motivation on the performance of employees of Balai Besar Bahan dan Barang Teknik (B4T) Bandung. Data analysis method used in this research is analysis of criteria range, multiple linear regression analysis and SEM-PLS analysis. The results showed that employee perceptions of training, placement, motivation and employee performance are good. The results of this study using multiple regression analysis showed that training, placement and motivation simultaneously affect the employee performance. Partially, motivation significantly affects the employee performance, but training and placement did not significantly affect employee performance. The result of SEMPLS analysis shows that motivation significantly affect employee performance, while training and work placement do not have real effect to the employee performance.
\end{abstract}

Keywords: employee performance, motivation, placement, training

\section{Introduction}

An increase in the secondary sector (industrial) and tertiary sector (services) in line with economic growth is the process of changing the economic structure (Todaro 1998). This condition occurs in Indonesia, with marked the movement of share from the primary sector (agriculture) to the secondary (industrial) and tertiary (services). This is as illustrated in Table 1, where within 15 years the industrial sector has increased from 13 per cent in 1965 to 47 per cent in 2010. The service sector in general has not shown any significant change although it tends to increase, except in 1980 . On by 2016, the contribution of the industrial sector including all services related to Indonesia's Gross Domestic Product (GDP) reaches 31.3 percent [1]. In terms of economic growth, Indonesia experienced a modest rebound in 2016 after experiencing an economic slowdown in 2011-2015 [2]. However, it certainly takes a long time to reach the government taget of economic growth of 7 percent in 2019.

Table 1: GDP Composition

\begin{tabular}{|l|c|c|c|c|}
\hline \multicolumn{1}{|c|}{ Sector } & 1965 & 1980 & 1996 & 2010 \\
\hline Agriculture & $51 \%$ & $24 \%$ & $16 \%$ & $15 \%$ \\
\hline Industrial & $13 \%$ & $42 \%$ & $43 \%$ & $47 \%$ \\
\hline Service & $36 \%$ & $34 \%$ & $41 \%$ & $38 \%$ \\
\hline
\end{tabular}

Source: Worl Bank on Indonesia Investment

The growth of the industry and services sectors as described above, is accompanied by the need for service quality improvement and competitiveness. Some ways that can be done is the development of industrial innovation centers supported by the improvement of human resources and the utilization of technological progress (Ministry of Industry
2017). One of the efforts in achieving this is to optimize the role of Center for Goods and Materials Engineering (B4T) located in Bandung. This institution is an agency under the Ministry of Industry that provides technical services to the industrial world. Along with the growth of secondary and tertiary sectors, as well as the conducive business climate, the number of $\mathrm{B} 4 \mathrm{~T}$ customers tend to increase as described in Table 1 .

Table 2: Number of B4T Customers 2012 - 2015

\begin{tabular}{|c|c|c|c|}
\hline \multirow{2}{*}{ No. } & \multirow{2}{*}{ Year } & \multicolumn{2}{|c|}{ Number of Customer } \\
\cline { 3 - 4 } & & Stay & Fixed \\
\hline 1. & 2012 & 1.693 & 476 \\
\hline 2. & 2013 & 1.603 & 530 \\
\hline 3. & 2014 & 1.656 & 576 \\
\hline 4. & 2015 & 2.195 & 731 \\
\hline
\end{tabular}

Source: Kemenperin 2016 [3]

Aforesaid conditions require that B4T management's readiness should improve the quality of its technical services, make time efficiency, and production costs in order to compete more competitively and to meet the needs of the industrial world. This goal can be achieved if B4T is supported by competent and qualified human resources. The optimum quality of human resources can be achieved through various strategic function approaches such as the application of change management and human resource quality innovation, motivation development, competency-based training, and various human resource development activities. [4][5].

Based on the literature study, there are three factors that are expected to have significant effect on the improvement of employee performance that can be attempted by B4T namely: 


\section{International Journal of Science and Research (IJSR) \\ ISSN (Online): 2319-7064}

Index Copernicus Value (2015): 78.96 Impact Factor (2015): 6.391

1) Training [6][7].Training aligned with organizational strategy can contribute to improving company performance helping employees acquire work-related knowledge based on their needs. [8][9].

2) Placement [10][11][12]. Placement are focused on the suitability and matching between skills and knowledge of people with job characteristics [13].

3) Motivation [14][15][16]. Motivation can be interpreted as the desire or the needs of someone background in performance improvement [17]. This condition is influenced by several factors such as ability, physical condition, intelligence, education and training, attitude, time and place [18].

The barriers facing B4T today are systems for improving performance, while on the other hand there is no known influence between the training that has been given to employees, the work placements that have been done, and the motivation on the performance of B4T employees. Therefore, this study aims to: (1) Analyze employee perceptions of training, placement, motivation and employee performance in B4T Bandung (2) Analyze the partial influence of training on employee performance in B4T Bandung. (3) Analyzing the partial influence of placement on employee performance in B4T Bandung. (4) Analyzing the partial influence of motivation on employee performance in B4T Bandung. (5) Analyze the effect of training, placement and motivation simultaneously on employee performance in B4T Bandung. This research will be focused on all civil servants (civil servants) as many as 112 people who work on B4T Bandung consisting of the administrative division, the field of engineering services development, the field of standardization, the field of certification, the field of engineering inspection, and functional group positions.

\section{Research Method}

The data research taken on July until August 2017 in B4T Office of the Ministry of Industry located on Jl. Sangkuriang No. 14 Bandung 40135Indonesia. The design of this research used descriptive research method with sensus technique to collect primary data. Measurement scale of this research is likert scale, used to measure attitude, opinion and perception of a person or group of people when asked to indicate their level of agreement or disagreement to each statement/social phenomenon. The approach used is multiple linnear regression using Partial Least Square (PLS) analysis tool. This model of analysis is part of Structure Equation Modeling and is used for reasons stated by Fornell and Bookstein (1982)[19]; Chin and Newsted (1999)[20], and Gefen et al. (2000)[21]: (1) Small sample and limited number of cases (2) Data is not multivariate, (3) There is an indication that the dependent variable is more than one. PLS can analyze all paths in a structural model simultaneously. The data used are primary data and secondary data. Primary data was obtained directly from respondents through questionnaires and in-depth interviews to some authorized officials in B4T Bandung. Secondary data obtained in the form of documents, literature, archives, reports related data personnel, tasks and functions B4T Bandung. This research will analyze employee's perception on training, placement, motivation and employee performance, and to analyze the effect of training, placement and motivation either partially or simultaneously on employee performance.

\section{Findings and Discussions}

\section{Characteristics of Respondents}

Respondents were 112 people consisting of administrative division, technical service development field, standardization field, certification field, engineering inspection field, and functional position group. The highest number of respondents was in the position of staff / implementers who numbered as many as 90 respondents or reached 80.4 percent of the total 112 respondents. The number of respondents in the position of Section Head/Section (level echelon 4) as much as 16 respondents or 14.3 percent for the position of Head of Section/Field (level echelon 3) as much as 5 respondents or 4.5 percent, and Head of B4T (level echelon 2) as a leader in $\mathrm{B} 4 \mathrm{~T}$ as much as 1 respondent or 0.9 percent.

In general, civil servants in B4T seen from the characteristics of respondents perceived age spread tend to be evenly distributed. However, respondents aged 23 years to 33 years who are young productive civil servants who can still be developed in the future occupy the smallest number of portions. Respondents in this study were men as much as 83 respondents or 74.1 percent and women as many as 29 respondents or 25.9 percent. This is because the job characteristics in $\mathrm{B} 4 \mathrm{~T}$ in the form of services related to technical matters relating to mechanics and manufacturing. Respondents with the last education at least Diploma three (D3) as many as 69 people or 61.7 percent. This shows that the services provided by B4T and B4T work programs have great potential to be improved and developed in the future. The working period of respondents most over 20 years as many as 40 people or 35.7 percent means the respondents are dominated by senior employees. Senior employees are more mature experience and competence, this is in accordance with the development of B4T business in the last decade that many require competent and experienced personnel.

\section{Respondents' Perceptions of Training, Placement, Motivation, and Performance}

Descriptive data to know the general description of respondents' answers, The analysis used is the analysis of criteria range. The smallest answer scale 1, the largest answer scale 5 and the number of classes by 5 , the interval class 0.80 . Perceptions of 112 respondents through the distribution of questionnaires on each variable are described in Table 2.

Table 3 Scores of respondents' perceptions of training, placement, motivation, and performance 


\section{International Journal of Science and Research (IJSR) \\ ISSN (Online): 2319-7064}

Index Copernicus Value (2015): 78.96 | Impact Factor (2015): 6.391

Table 3: Scores of respondents' perceptions of training, placement, motivation, and performance

\begin{tabular}{|c|c|c|c|c|c|}
\hline & $\mathrm{Nu}$ & Indicator & ATS & TS & Expl. \\
\hline & 1 & Readines & 441 & 3.94 & Agree \\
\hline & 2 & Ability & 436 & 3.89 & Agree \\
\hline & 3 & Training material & 436 & 3.89 & Agree \\
\hline & 1 & Education & 449 & 4.01 & Agree \\
\hline & 2 & Knowledge & 452 & 4.03 & Agree \\
\hline & 3 & Skillful & 449 & 4.01 & Agree \\
\hline & 4 & Experience & 437 & 3.90 & Agree \\
\hline & 1 & Quality supervision & 422 & 3.77 & Agree \\
\hline & 2 & Relationship & 449 & 4.01 & Agree \\
\hline & 3 & Working condition & 391 & 3.49 & Agree \\
\hline & 4 & Company policy & 436 & 3.89 & Agree \\
\hline & 5 & Salary & 390 & 3.48 & Agree \\
\hline & 6 & Job characteristic & 421 & 3.76 & Agree \\
\hline & 7 & Recognition & 413 & 3.76 & Agree \\
\hline & 8 & Achivement & 456 & 4.07 & Agree \\
\hline & 9 & Responsibillity & 423 & 3.77 & Agree \\
\hline & 10 & Development & 427 & 3.81 & Agree \\
\hline & 11 & Work security & 415 & 3.70 & Agree \\
\hline & 1 & Number of jobs & 438 & 3.91 & Agree \\
\hline & 2 & Quality & 431 & 3.84 & Agree \\
\hline & 3 & Punctuality & 447 & 3.99 & Agree \\
\hline & 4 & Presence & 4.01 & Agree \\
\hline
\end{tabular}

Table information. $\mathrm{Nu}=$ Number; ATS= Avarage Total Score; AS= Avarage Score; Expl= Explanation

Respondents' perceptions of all variables are perceptible both with the statement of agreement (3.41-4.20), with each score scores for the training scores average score 3.91, placement score average score 3.99 , motivation average score 3.77 and employee performance score 3.89. Thus the perception of respondents to all indicators is also good.

\section{Validity and Reliability}

Validity test is used to determine the eligibility of the items in a statement in defining a variable. If the Pearson Correlation value of each statement is greater than 0.3 then the statement item is considered valid. Result of validity test of variable of training, placement, motivation and employee performance is known all value of pearson correlation above 0.3 hence can be concluded all item of statement is valid. A variable is considered reliable if the value of cronbach alpha> 0.60. The test results showed that all the variables of training, placement, motivation and employee performance have cronbach alpha> 0.60 meaning that all variables are reliable (reliable).

\section{Classic assumption \\ Normality test}

SPSS results show the data spread around the diagonal line so it can be concluded the data is normally distributed or meet the requirements of normality. The information is presented in Figure 1.

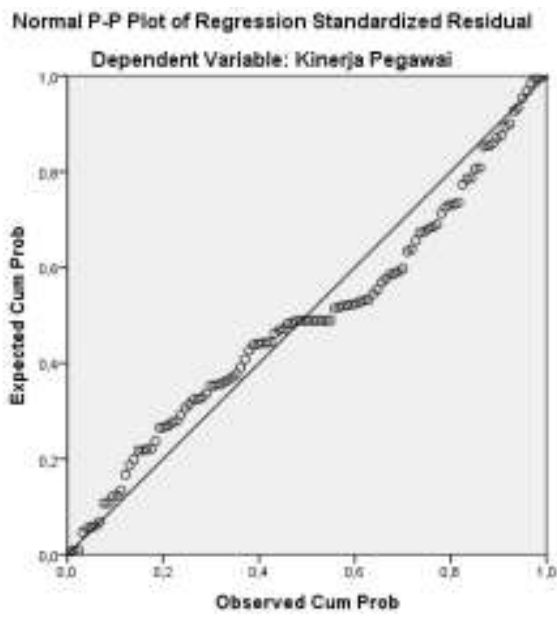

Figure 1: Normality test result

\section{Multicolinearity Test}

The multicollinearity test knows whether or not there is correlation between independent variables with the other independent variables. This research does not have multicollinearity because the statistic tolerance value of each variable away from value 0.01 and VIF value (Variance Inflaction Factor) each variable is smaller than $10(1.568$ $<10 ; 1.457<10 ; 1.962<10)$. 


\section{International Journal of Science and Research (IJSR) \\ ISSN (Online): 2319-7064}

Index Copernicus Value (2015): 78.96 | Impact Factor (2015): 6.391

Heteroscedasticity Test

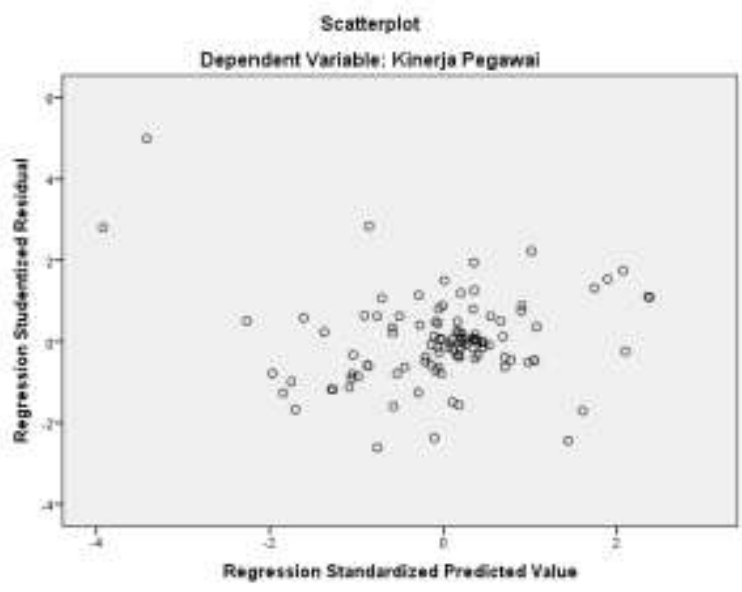

Figure 2: Scatter plot

Figure 2 shows the distribution of random dispersed residual data does not form a certain pattern, it can be said homoskedastisitas or no heteroscedasticity. Regression model is suitable to be used to predict employee performance based on free variable of training, placement, and motivation.

\section{Analysis of SEM-PLS \\ Evaluation of measurement models}

Table 4 shows that all indicators have load factor value $>0.5$, meaning that all indicators meet the criteria of the latent convergent validity test. Indicates there is no indicator that has a loading factor value $<0.5$ so no need for an indicator is removed from the model.

The model requirement has good validity if each latent variable with reflective indicator has AVE> 0.5. The results of the analysis seen in Table 6, the AVE value of each latent variable has a value> 0.5 and it can be said that the PLS model meets the terms of good convergent validity.

Table 4: value average variance extraxted (AVE) and composite reliability

\begin{tabular}{|c|c|c|}
\hline Variabel & AVE & $\begin{array}{c}\text { Composite } \\
\text { Reliability }\end{array}$ \\
\hline Kinerja Pegawai (performance) & 0.6369 & 0.8973 \\
\hline Pelatihan (training) & 0.8052 & 0.9254 \\
\hline Penempatan (placement) & 0.7938 & 0.9389 \\
\hline Motivasi (motivation) & 0.6363 & 0.9503 \\
\hline
\end{tabular}

Reliability test by measuring composite reliability to latent variables having value $>0.6$ is said to be reliable. The results based on Table 5 show that all latent constructs have good reliability, accurate and consistent because they qualify with the composite reliability value of each latent construct $>0.6$. Discriminant validity testing is conducted on the principle that different construct manifest variables should not be highly correlated. Table 5 shows that the correlation value between constructs as a whole has been less than the value of $\sqrt{ }$ AVE can be said that the model has met the requirements of discriminant validity.
Table 4: Correlation matrix

\begin{tabular}{|c|c|c|c|c|}
\hline & $\begin{array}{c}\text { Kinerja } \\
\text { Pegawai } \\
\text { (Performance) }\end{array}$ & $\begin{array}{c}\text { Motivasi } \\
\text { (Motivation) }\end{array}$ & $\begin{array}{c}\text { Pelatihan } \\
\text { (training) }\end{array}$ & $\begin{array}{l}\text { Penempatan } \\
\text { (placement) }\end{array}$ \\
\hline $\begin{array}{c}\text { Kinerja } \\
\text { Pegawai } \\
\text { (performance) }\end{array}$ & $\begin{array}{c}\sqrt{\mathrm{AVE}}= \\
0.798\end{array}$ & & & \\
\hline $\begin{array}{c}\text { Motivasi } \\
\text { (motivation) }\end{array}$ & 0.690 & $\begin{array}{c}\mathrm{VVE}= \\
0.797\end{array}$ & & \\
\hline $\begin{array}{c}\text { Pelatihan } \\
\text { (training) }\end{array}$ & 0.512 & 0.593 & $\begin{array}{c}\mathrm{AVE}= \\
0.897\end{array}$ & \\
\hline $\begin{array}{c}\text { Penempatan } \\
\text { (placement) }\end{array}$ & 0.483 & 0.579 & 0.366 & $\begin{array}{c}\mathrm{AVE}= \\
0.890\end{array}$ \\
\hline
\end{tabular}

The coefficient results show a positive coefficient of 0.160 indicating that the increase of 1 score of motivation (X3) will improve employee performance (Y) of 0.160 Score, or in other words can be explained:

The value of $t$ count for motivation variable (X3) of 5.176 or significance p-value) $0.000<\alpha=0.05$ then reject H0 means motivation variable (X3) have real effect on employee performance variable (Y).

\section{Evaluation of Structural Model}

Table 6 shows that training (X1) has no significant effect on employee performance $(\mathrm{Y})$ with a statistical $t$ value of 1.253 $<$ t table (1.96). Likewise with the placement (X2) does not significantly affect employee performance (Y) with a statistical $t$ value of $1.283<t$ table (1.96). Motivation (X3) has a significant effect on employee performance of 0.5293 meaning that the better the motivation the better the performance of the employee (Y) which is re fl ected by X31 - X311 (quality of supervision - job security) and employee performance which is re fl ected by Y1 - Y5 - ability of cooperation). This study supports the results of previous studies as conducted by Springer (2010), Aarabi et al. (2013), and Setiawan (2015).

The structural model of employee performance resulted in Rsquare value of 50.20 percent means that the diversity of employee performance can be explained by the model of 50.20 percent while the remaining 49.80 percent is explained by other factors outside the model.

Table 6: Loading factor value and t-statistic

\begin{tabular}{|c|c|c|c|}
\hline & $\begin{array}{c}\text { Loading } \\
\text { factor }\end{array}$ & T-statistic & R square \\
\cline { 1 - 3 } Motivation > Performance & 0.5293 & 4.080 & \multirow{2}{*}{0.5020} \\
\cline { 1 - 3 } Training > Performance & 0.1539 & 1.253 & \\
\hline Placement > Performance & 0.1202 & 1.283 & \\
\hline
\end{tabular}

*) Significant 5 percent level

\section{Managerial Implications}

The results of this study provide some implications, among others: (1) B4T needs to continue to provide good assessment for employees who excel and reward them for encouraging them to achieve higher work performance. 


\section{International Journal of Science and Research (IJSR) \\ ISSN (Online): 2319-7064}

Index Copernicus Value (2015): 78.96 | Impact Factor (2015): 6.391

(2) Implementation of training needs analysis in terms of identification of organization needs, B4T needs to be done well. (3) To prepare the trainees for proper training, information about the training, the requirements of the trainees prior to training should be notified a few days before the training. (4) Implementation of training assessments has been done at the level of the participants' reactions through feedback that is always given when the participant completes the training. Assessment at the learning level has also been conducted before (pre-test) and after (post-test) training. (5) B4T should continue to pay attention to employee skills in order to speed up the completion of work and to provide workload in accordance with the ability of employees. (6) Placement of employees in B4T must still pay attention to education, knowledge, skills and experience.

\section{Conclusions and Suggestions}

\section{Conclusion}

The conclusions of this research are: (1) Employees have a good perception of training, placement, motivation and employee performance. (2) Training has no significant effect on employee performance, because the training process starts from the training needs planning, training program design, training implementation, and training appraisal has not been implemented properly. (3) Work placement does not have a significant effect on employee performance, because the employee placement process is less concerned with education, knowledge, skills and experience. (4) Motivation significantly influence the performance of employees, because the factors in improving motivation has been done well. (5) Training, placement and motivation simultaneously affect employee performance.

\section{Suggestion}

The recommendations are: (1) Each stage of the training needs to be done well starting from the training planning, implementation and evaluation. (2) The ability of superiors in providing guidance, direction, or praise needs to be improved, because it will have an impact on employee motivation. (3) Programs to improve employee relations need to be continuously pursued to keep employee motivation maintained. (4) B4T should continue to improve the rewards system on employee performance related to the provision of technical service provision abroad. (5) The explanation of the development and future of B4T is necessary to continue to be conveyed to the employee so that employees feel secure the continuity of their work.

\section{References}

[1] [BPS] Badan Pusat Statistik. 2017. Pertumbuhan ekonomi IndonesiatTriwulan I-2017. Berita Resmi Statistik No. 45/05/Th.XX. Jakarta (ID): BPS.

[2] [Indonesia Investment] Indonesia Investment Van der Schaar Investments B.V. 2017. Produk Domestik Broto Indonesia. [online] [accessed 2017 Dec 3]. Available on https://www.indonesia- investments.com/id/keuangan/angka-ekonomi-

makro/produk-domestik-bruto-indonesia/item253?

[3] [Kemenperin] Kementerian Perindustrian. 2016. Data Jumlah Pelanggan B4T 2012 - 2015. Jakarta(ID): Kemenperin.

[4] Mangkuprawira S, Hubeis AVS. 2007. Manajemen Mutu Sumber Daya Manusia. Jakarta (ID): PT. Ghalia.

[5] Marlinah L. 2011. Analisis strategi konteks manajemen sumber daya manusia. Jurnal Widya Cipta 1(1): 1-8.

[6] Sultana A, Irum S, Ahmed K, Mehmood N. 2012. Impact of training on employee performance: a study of telecomunication sector in Pakistan, Interdisciplinary Journal of Contemporary Research in Business. 4(6): 646661.

[7] Wicaksono YS. 2016. Pengaruh pelatihan dan pengembangan sumber daya manusia dalam rangka meningkatkan semangat kerja dan kinerja karyawan (studi di SKM unit V PT. Gudang Garam,Tbk Kediri). Jurnal Bisnis dan Manajemen 3(1): 31-39.

[8] Thang NN, Buyens D. 2008. Training, Organizational Strategy and Firm Performance, Business Review Cambridge. 11(2):176-183.

[9] Pritchard N. 2010. Learning and performance journeys. Industrial and Commercial Training. 42(6):303-308. doi:10.1108/00197851011070668.

[10] Aldilaningsari Y, Al Musadieq M, Hakam MS. 2014. Pengaruh penempatan kerja terhadap kinerja (studi pada karyawan PT. Bank Jatim cabang Malang). Jurnal Administrasi Bisnis 9(1): 1-7.

[11] Atkhan A, Margono, Riady G. 2013. Pengaruh penempatan kerja terhadap kinerja pegawai pada dinas perkebunan provinsi Kalimantan Timur. Journal Administrative Reform 1(1): 257-271.

[12] Runtunewe P. 2016. Pengaruh penempatan kerja, mutasi dan beban kerja terhadap kinerja karyawan pada PT. Bank Sulutgo Manado. Jurnal Berkala Ilmiah Efisiensi 16(1): 169-237.

[13] Mathis RL, Jackson JH. Human resource management: Essential perspectives. Cengage Learning; 2011 Jun 16.

[14] Springer GJ. 2010. Job motivation, satisfaction and performance among bank employees: a correlation study [disertasi]. Arizona (US): Northcentral University.

[15] Aarabi MS, Subramaniam ID, Akeel ABAAB. 2013. Relationship between motivational factors and job performance of employees in Malaysian service industry. Asian Social Science. 9(9): 301-310. doi:10.5539/ass.v9n9p301.

[16] Setiawan. 2015. Pengaruh motivasi kerja terhadap kinerja karyawan level pelaksana di divisi operasi PT. Pusri Palembang. Jurnal Psikologi Islam 1(2): 43-53.

[17] Cahyanugroho A, Hubeis M, Wijayanto H. 2016. The effect of remuneration on motivation that implicates employee's performance in XYZ company. Indonesian Journal of Business and Entrepreneurship, 2(2): 112 121.

[18] Fandianto L, Sutanto EM. 2012. Effectiveness analysis of "Shangri-La Academy Program" towards employees working motivation at Shangri-La Hotel Surabaya, Journal of Indonesian Economy and Business. 27(3): 406-417. 
[19] Fornell C, Bookstein LF. 1982. Two structural equation models: LISREL and PLS applied to consumer exitvoice theory. Journal of Marketing Research 9(10): 443-448.

[20] Chin WW, Newsted PR. 1999. Structural Equation Modeling Analysis with Small Samples Using Partial Least Squares, in Statistical Strategies for Small Sample. Research. Rick Hoyle (ed.) Thousand Oaks (CA): Sage Publications.

[21] Gefen D, Straub DW, Boudreau MC. 2000. Structural equation modeling techniques and regression: guidelines for research practice. Communications of the Association Information Systems. 1(7): I78

\section{Author Profile}

Ekko Harjanto. A student of Postgraduated Program of Management and Business, Bogor Agricultural University, Jl. Raya

Pajajaran, Bogor - Indonesia

Volume 6 Issue 12, December 2017

www.ijsr.net 